\title{
Vloga in pomen islamskega prava
}

UDK: $28: 34$

\author{
Alenka Kuhelj \\ Univerza v Ljubljani, Fakulteta za upravo \\ alenka.kuhelj@fu.uni-lj.si \\ Jasna Halilović
}

\section{IZVLEČEK}

Islamsko pravo ima svojo osnovo v religiji, s katero je tako tesno povezano, da ju ni mogoče ločiti, zato se postavlja vprašanje, ali je islamski svet zmožen oziroma pripravljen sprejeti sekularizem in s tem državo ločiti od religije, kar bi pomenilo opustitev šeriata ter strogo ločitev verskega od posvetnega. Le tako lahko namreč islamski svet prevzame pravo in preizkušene pravne institute zahodnega sveta.

Avtorici se $v$ članku lotevata problematike vloge islama in islamskega prava $v$ zahodnih demokratičnih državah, ki je danes pomembna ne samo $z$ vidika verske (ne)nevtralnosti oziroma (ne)krščanskosti na zahodu, temveč tudi s pravnega vidika, tako migracijskega, delovnega, socialnega in nenazadnje kazenskega prava. $V$ članku najprej zelo izčrpno in celovito predstavita tako zgodovinske posebnosti islama kot tudi izvor, pomen in sistematiko samega islamskega prava, ki spada $v$ skupino religioznih pravnih sistemov, za katerega je značilno, da je religija v tolikšni meri dominantna, da neposredno določa tudi vsebino prava, zato takšnega prava ni mogoče opredeliti kot sodobno pravo. $V$ drugem delu članka teretično izsledke temeljito nadgradita $z$ zelo aktualnimi primeri sodobnega časa, kot so npr. institut zakonske zveze $v$ islamskem pravu, zakrivanje žensk, primer nošenja naglavnih rut $v$ Turčiji ter problem nošenja pokrival v javnih šolah v Franciji...

Ključne besede: islam, zgodovina islama, islamsko pravo, viri islamskega prava, institut zakonske zveze, kazensko pravo.

\section{Uvodne misli}

Samuel P. Huntington je današnji svet označil kot svet civilizacijskih nasprotij in kulturnih vojn, torej kot neke vrste "Kulturkampf ". Njegove ideje so precej podobne idejam bivšega nemškega kanclerja Helmuta Schmidta o tem, da je soobstoj islama in krščanstva mogoč samo $v$ avtoritarnih državah. Takšne apokaliptične napovedi so nevarno zavajajoče, saj islam $\vee$ zahodnem svetu (Severna Amerika in Evropa) izpostavljajo kot religijo, ki vodi h globalnemu miru ali $k$ vojni. Omenjenemu in $v$ zadnjem času prevladujočemu stališču o problemu islama $\vee$ zahodnih demokracijah pa obstajajo tudi nasprotne, bolj strpne 
Alenka Kuhelj, Jasna Halilović

Vloga in pomen islamskega prava

napovedi, ki vidijo v islamu religijo, ki ji mora zahodni svet "podati roko«, saj gre za najhitreje rastočo monoteistično religijo na svetu.

Nesmiselno bi bilo ugovarjati dejstvu, da si vrednote zahodnega in islamskega sveta prihajajo $v$ navzkrižje, vendar pa je pomembno pri tem izpostaviti tudi dejstvo, da se $v$ navzkrižju nahajajo tudi evropske politične stranke, predvsem sekularne in konzervativne. Pri tem gre torej za vprašanje verskega pluralizma, ki odpira nerešeno vprašanje "evropske javne identitete" in s tem evropske dvotirnosti (državna nevtralnost $\vee$ zadevah religije ali pomemben položaj krščanstva $\vee$ državni strukturi).

Problematika vloge islama in islamskega prava $v$ zahodnih demokratičnih državah je danes pomembna ne samo z vidika verske (ne)nevtralnosti oziroma (ne)krščanskosti na zahodu, temveč tudi s pravnega vidika, tako migracijskega, delovnega, socialnega in nenazadnje kazenskega prava.

\section{Zgodovinsko-izvorne posebnosti islama}

Islamsko pravo je za zahodni svet zanimivo glede na to, da temelji na veroizpovedi, oziroma na veri $v$ enega Boga (Alaha) in njegovega poslanca Mohameda, medtem ko za razliko od tega zahodni pravni sistem temelji na strogi ločitvi verovanja (in veroizpovedi) od posvetnega prava.

Islam je najmlajša svetovna religija, ki je zaznamovala zgodovino in pravni razvoj celotnega arabskega sveta. Nastanek te vere sega $\vee 7$. stoletje $n$. št. na arabski polotok (ozemlje današnje Savdske Arabije). Verniki verjamejo, da je bila božja volja razodeta prek poslanca Mohameda, ki je vero širil med takratno ljudstvo. Božja beseda je bila zapisana v Koranu, ki je sveta knjiga muslimanov, čeprav je nastal šele po Mohamedovi smrti. Takrat so bila zapisana tudi Mohamedova navodila, t.i. suna.

Po Mohamedovi smrti se je vnel spor zaradi različnih tolmačenj glede upravičenosti do njegovega nasledstva. Ta spor je povzročil globok razdor $v$ islamski skupnosti in je še danes eden glavnih vzrokov za očitna neskladja med muslimani. Zaradi razdora se danes islam deli na dve pomembnejši ločini, in sicer na večinske sunite (90 \%) in na šiite (10 \%) (Kečanović v: Kuhar, 2007, str. 7).

Suniti so verniki tradicije suna. Za njih je značilno svojstveno razumevanje Mohamedovega nasledstva. Suniti namreč verjamejo, da so bližnji Mohamedovi moški sorodniki iz plemena Kurjaš Mohamedovo nasledstvo, ki ga predstavlja kalif. Mohamed pred smrtjo namreč ni dal navodil o tem, kdo naj vodi 
umo - skupnost muslimanov. Za prvega kalifa štejejo Abu Bakhra, ki je tako kot Mohamed združeval politično in versko oblast. Vodil je javne molitve in s silo obvladoval skupnost. Predstavljal je tudi vrhovno avtoriteto razlage Korana. Primarna pravna pravila sunitov so Koran in hadisi. Vse spremembe doktrine, ki niso v skladu s suno, štejejo suniti za napačne (Smrke, 2000, str. 268).

Šiiti so pripadniki šie oziroma privrženci Alija, ki ga štejejo za legitimnega naslednika Mohameda Alija, ki je bil Mohamedov bratranec in zet (poročen z Mohamedovo hčerjo Fatimo). Za šiite so prvi trije kalifi, ki jih priznavajo suniti, nesprejemljivi. Po prepričanju šiitov naj bi Mohamed tik pred svojo smrtjo bratranca Alija uvedel v najgloblje skrivnosti islama, on pa naj bi znanje prenesel na svojo družino, zlasti na sinova Hasana in Huseina. Sunitska umajidska dinastija tovrstnega nasledstva ni nikoli priznavala, čeprav je sprejemala Alija kot četrtega kalifa. Mohamedovi nasledniki so v šiizmu šteti za imame - vodnike, čuvarje skrivnih znanj oz. vedenj. Ali je bil prvi, Hasan drugi in Husein tretji imam. Avtoriteta imama sloni na sorodstveni povezanosti z Mohamedom, na poznavanju skritega pomena Korana (tavil) in na božanski navdihnjenosti (ilham). Imam naj bi bil nezmotljiv, božanski, edini pravi razlagalec islama - torej človeška manifestacija božjega. Šiiti imama štejejo za "šesti steber « islama, kar je ena ključnih doktrinarnih razlik s sunizmom. Suniti uporabljajo izraz imam za vodjo molitve v mošeji (Smrke, 2000, str. 268).

Islam je poleg krščanske in judovske vere eno izmed treh največjih svetovnih monoteističnih verstev sveta. Je najmlajša, a hkrati tudi najhitreje rastoča religija. Vse tri vere imajo skupno izhodišče in se islam tudi nanju navezuje, vendar s prepričanjem, da ju nadgrajuje in presega. Zagovorniki islama to utemeljujejo z dejstvom, da islam za razliko od krščanstva in judovstva pokriva vsa področja človekovega delovanja. Vsebuje namreč, poleg same vere, tudi moralna in družbeno-pravna pravila. Gre za celovit življenjski sistem, ki naj ne bi puščal nobenega vprašanja brez odgovora. Zato pripadniki islamske vere verjamejo, da islam ni le molitev in ljubezen do Boga, ampak veliko več (Sedgwick v: Kuhar, 2007, str. 7).

$\checkmark$ skladu $z$ islamom imajo muslimani naslednje osnovne dolžnosti, ki predstavljajo pet stebrov islamske vere (šartı):

1. Izjavljanje pripadnosti veri (šahada), ki se izjavlja večkrat dnevno. "Ni boga razen Alaha in Mohamed je njegov poslanec. "

2. Opravljanje obredne molitve (namaz), ki se opravlja petkrat dnevno ob določenem času. Od trenutka muezinovega klica in predhodnega obrednega umivanja je namaz skupnostno dejanje. Izraz tega je skupna smer 
Alenka Kuhelj, Jasna Halilović

\section{Vloga in pomen islamskega prava}

(proti Kaabi v Meki), kamor se obrnejo vsi muslimani pri molitvi. Po vsem svetu so vsi združeni $v$ smeri in namenu in oblikujejo sklenjen krog častilcev. Molitev vodi imam. (Kerr v: Munh, 1998, str. 10).

3. Izvajanje posta $\vee$ postnem ramadanu (ramazan). $\vee$ tem času je predpisan strogi post od zore do mraka. To je tudi čas duhovnosti in očiščevanja. Muslimani imajo dva praznika - Bajrama. Eden je po koncu Ramadana in traja tri dni, drugi je Hadž Bajram in traja 4 dni (http://sl.wikipedia.org/wiki/Ramadan).

4. Obvezno islamsko darovanje oziroma plačilo nekakšnega davka (zekat) - gre za dolžnost tistih muslimank in muslimanov, ki presegajo s šeriatom določeno količino bogastva (nisab).

5. Romanje $\vee$ Meko (Hadž), ki se ga mora vsaj enkrat v življenju udeležiti vsak odrasel in polnoleten musliman, ki je zdrav in ima dovolj finančnih sredstev, da si to lahko privošči. Verniki morajo najprej hitro, nato pa počasi obkrožiti Kaabo-kocko na dvorišču džamije v Meki. (http://sl.wikipedia.org/ /wiki/Had\%C5\&BE.)

Zaradi velike množice ljudi so se $\vee$ preteklosti pogosto dogajale tragedije, saj je nenadzorovana množica poteptala nekatere vernike. Nesreče pa so se dogajale tudi med obrednim kamenjanjem treh stebrov, ki predstavljajo hudiča, saj so ljudje zaradi udarcev kamnov umrli. Tragedije, ki se dogajajo $v$ času romanja, pa so na žalost največkrat plod neorganiziranosti oziroma prevelikega transa ljudi, ki v želji, da vse obredne točke izvedejo kar se da pravilno, pozabljajo na varnost tako sebe kot drugih. Problem je tudi v komunikaciji, saj večina Savdijcev ne govori angleškega jezika, tisti, ki pridejo na Hadž, pa ne govorijo ne arabsko ne angleško.

Dandanes je približno 22 odstotkov od 6,3 milijarde svetovnega prebivalstva islamske veroizpovedi, kar pomeni 1,4 milijarde muslimanov. Živijo $v$ glavnem na območju zahodne in severne Afrike, na Bližnjem vzhodu, $v$ centralni Aziji, Iranu ter v južni Aziji vse do Indonezije. Zunaj tega pasu živi okoli 40 milijonov muslimanov, in sicer na Kitajskem in v Rusiji. Poleg tega pa živijo tudi na Zahodu, približno 5 milijonov jih živi v Združenih državah Amerike in okoli 20 milijonov v Evropi (Sedgwick v: Kuhar, 2007, str. 8).

Za islam je značilno, da to ni zgolj religija, ampak so obenem to tudi navodila za celotno življenje muslimanov, saj vsebuje pravila pravne in socialne narave, ki posegajo na vsa področja posameznikovega življenja. Beseda islam je arabskega izvora in pomeni predanost Bogu. Izvira iz besede selam, kar pomeni mir. Omenjena predanost se kaže $z$ verovanjem $\vee$ Alaha, z 
izvrševanjem vseh islamskih predpisov in dolžnosti ter s primernim obvladovanjem in obnašanjem.

Islamsko pravo, kot ga poznamo danes, se je začelo oblikovati že $v$ času življenja Mohameda, skozi stoletja pa se je preoblikovalo s pomočjo štirih sunitskih šol prava, ki so odigrale ključno vlogo $v$ razvoju islamske pravne znanosti.

$\checkmark$ današnjem svetu se $v$ vsakdanjem življenju srečujemo $z$ ljudmi različnih kultur in prav sodobni način življenja je povzročil večjo intenzivnost stikov med različnimi kulturami, zato obstaja toliko večja potreba po medsebojnem poznavanju.

$\mathrm{Na}$ Zahodu obstaja neracionalen strah pred muslimani in islamsko vero, lahko bi rekli pred vsem, kar je islamsko. Islam se največkrat povezuje z negativnimi pojmi, kot so fundamentalizem, terorizem in kršenje človekovih pravic. $V$ očeh nekaterih nemuslimanov so te predstave nastale predvsem kot posledica nepoznavanja, neupravičenega posploševanja in strahu pred drugačnim. Ravno zaradi tovrstnih predsodkov je proces medsebojnega spoznavanja in prilagajanja ključnega pomena.

Islamski svet je skozi kolonialna podrejanja prišel v neposreden stik z evropskim pravom in kulturo. Ta stik je imel globok vpliv na razmišljanje in obnašanje mnogih muslimanov in je botroval $k$ temu, da so se pojavila različna duhovna razmišljanja, ki so vsekakor pustila pečat na islamski pravni misli in v praksi. $\vee$ grobem pa lahko govorimo o treh usmeritvah, ki so se pojavile $\vee$ pravni teoriji in praksi islamskega sveta $v$ tem obdobju; to so prevzemanje evropskega prava, prepletanje šeriatskega in evropskega prava in poskus posodabljanja islamske pravne znanosti (Karičić, 1997, str. 127).

Približno od srede 19. stoletja se je korenito spremenil položaj islamskega prava $\vee$ večjem delu islamskega sveta. Najprej $\vee$ otomanskem cesarstvu, nato pa $\vee$ »angleški Indiji in drugje je vpliv sodobnega življenja zmanjšal moč šeriata predvsem na dva načina. Prva sprememba je očitna: na mnogih področjih življenja so šeriat zamenjali novi zakoniki, ki so bili v veliki meri izpeljani iz prava zahodnega sveta. $\vee$ otomanskem cesarstvu so npr. v petdesetih in šestdesetih letih 19. stoletja nastali trgovski zakonik, kazenski zakonik, zakonik o trgovskem postopku in zakonik o pomorski trgovini, ki so vsi temeljili na francoskih vzorcih. Ko pa so otomanski reformatorji prišli do obligacijskega prava (pogodbe, prekrški itd.), so začeli razpravljati, ali naj si spet vzamejo za vzor evropsko pravo ali naj skušajo sestaviti ustrezen zakonik na osnovi islamskih virov. Končno je prevladalo drugo stališče. Tako je nastala madžala (dokončali so jo 


\section{Alenka Kuhelj, Jasna Halilović \\ Vloga in pomen islamskega prava}

leta 1876), ki je bila sestavljena iz razsodb izbranih sunitskih pravnikov, ki pa jih je vse priznavala tudi hanafijeva šola. Madžala je imela ogromen pravni pomen. Prvič v zgodovini je državna oblast uveljavila zakonik, ki je temeljil na načelih, izpeljanih iz šeriata. In prav tako so prvič zbrali predpise različnega izvora glede na njihovo primernost za sodobno življenje in ne glede na njihovo uveljavljenost $\checkmark$ določeni šoli. Vse te nove zakonike so tudi uporabljali na sodiščih, katerih osebje se je šolalo v sodobnih pravnih šolah. Le družinsko pravo se je še naprej uporabljalo $v$ standardni obliki na šeriatskih sodiščih brez zakonika in reforme. Druga sprememba je bila manj očitna, vendar prav tako pomembna. Leta 1915 je množica muslimanskih žena, ki so bile še vedno pod oblastjo hanafijevih predpisov, dobesedno prisilila sultana, da je posegel tudi $\vee$ družinsko pravo. Izdal je dva dekreta, ki sta dovoljevala ženam, da zahtevajo sodno razvezo zakona $v$ nekaterih okoliščinah, ki jih je spremljala katera od sunitskih šol. Ko je bil jez enkrat odprt, je poplava hitro prodrla $\vee$ notranjost. Leta 1917 so razglasili otomanski zakon o družinskih pravicah, ki je temeljil na razširjeni uporabi teh načel (Anderson v: Munh, 1998, str. 28).

Enako se je dogajalo tudi v drugih islamskih deželah. V »angleški Indiji« so seveda novi svetni zakoniki temeljili bolj na angleškem običajnem pravu (common law) kot na francoskem državljanskem pravu. Tu so svetno pravo in nezapisano družinsko pravo različnih verskih skupnosti obravnavala ista sodišča. Nasprotno pa so $\vee$ Turčiji odpravili šeriat in namesto njega sprejeli prilagojeno evropsko pravo. Opomniti pa je treba, da je Turčija od časov Atatürka sekularna država, ki ni niti zapovedovala niti prepovedovala sledenje šeriata. Država je imela svoje zakone. Po drugi strani pa v Savdski Arabiji še vedno velja šeriat, čeprav je tudi tam vedno več svetnih predpisov. Vendar ima sedaj večina islamskih dežel $v$ glavnem svetne zakone, razen $v$ družinskem pravu, za katerega vsi vztrajajo, da mora ostati izrazito islamsko in celo tega so $\checkmark$ celoti ali delno uzakonili $\vee$ obliki, ki je bolj primerna za sodobno življenje. $\vee$ deželah, kot sta Somalija in Ljudska republika Jemen, je marksističen vpliv na pravo očiten (Anderson v: Munh, 1998, str. 28).

Islamske države, ki so prišle pod protektorat evropskih sil, so vseeno v veliki meri zadržale in ohranile tradicionalni sistem islamskega prava. Protektorat kot oblika kolonialne dominacije je sprejemal zadrževanje notranjih družbenih in pravnih ustanov posamezne države in tako je status quo ohranjen npr. v Tuniziji, Maroku in Severni Nigeriji.

Do ukinitve šeriatskega prava $\vee$ azijskem delu pa je prišlo po oktobrski revoluciji, ko so bile skupnosti ločene od države in je vera postala zasebna 
zadeva državljanov. Ukinitev šeriatskega prava je izvršena $v$ skladu z načelom, da vsi pravni in sodnoprocesni akti preidejo $v$ pristojnost takratne komunistične Rusije (Karčić, 1997, str. 133).

Tako je sedanje stanje $v$ marsičem drugačno kot $v$ preteklosti. Medtem ko je nekoč šeriat v muslimanskih deželah prevladoval, je sedaj večinoma omejen na družinsko pravo. Vseeno pa vse bolj narašča težnja po oblikovanju državljanskih zakonikov, ki bi vključevali načela islamskega prava hkrati z načeli posvetnega nacionalnega prava. Nekatere države so $v$ zadnjem času začele celo ponovno uvajati kazni za kazniva dejanja, ki so določena $\vee$ šeriatskem pravu. $\vee$ večini islamskih držav pa je sedaj pravo, ne glede na svoj izvor, trdno zasidrano z zakonskimi predpisi. Tako je avtoriteta prava, ki je bila nekoč le posredna in prehodna, $v$ večini držav ustavno utemeljena in izraža voljo ljudstva. Četudi je danes šeriat nepopolno prakticiran $v$ večini islamskih držav, je še vedno $\vee$ zavesti muslimanov kot idealno pravo, ki ima svoj popoln namen (Anderson v: Munh, 1998, str. 30).

\section{Izvor, pomen in sistematika islamskega prava}

Za islamsko pravo, ki spada $\vee$ skupino religioznih pravnih sistemov, je značilno, da je religija $\vee$ tolikšni meri dominantna, da neposredno določa tudi vsebino prava (izjema je sekularna Turčija), zato takšnega prava ni mogoče opredeliti kot sodobno pravo. Temeljne značilnosti sodobnega prava so povezanost s sodobno državo, individualizem, priznanje civilne družbe, splošnost, abstraktnost, formalizem, sistematičnost, racionalizem, sekularnost, visoka stopnja avtonomnosti ter načelo pravne države (Cerar v: Kuhar, 2007, str. 13). Pri primerjavi temeljnih značilnosti sodobnega prava $z$ islamskim pravom lahko ugotovimo nižjo stopnjo udejanjanja pravne države, sekularnosti, visoke stopnje avtonomnosti ter priznavanje civilne družbe in individualizma. Vse te razlike otežujejo vključevanje človekovih pravic $v$ islamsko pravo. Večina islamskih pravnikov je zaradi tega prepričanih, da lahko človekove pravice obstajajo le $\mathrm{v}$ sekularnih pravnih sistemih, zaradi česar jih zavračajo kot nekaj tujega in nezdružljivega z verskim sistemom (http://www.religiousconsultation.org/Hassan 2.htm v: Kuhar, 2007, str. 14). Oviro predstavlja tudi prepričanje, da je islamsko pravo večno in nespremenljivo za vse čase, zato naj ga ne bi podrejali pritiskom zahodnega sveta (Grasmann in David v: Kuhar, 2007, str. 14). Med muslimani je mogoče zaslediti tudi stališče, da so vrednote, ki jih varujejo človekove pravice, enake kot tiste vrednote, ki so vključene $v$ islamsko pravo že od njegovega 


\section{Alenka Kuhelj, Jasna Halilović \\ Vloga in pomen islamskega prava}

nastanka. Vendar nekatere islamske države pristopajo $\mathrm{k}$ mednarodnim pogodbam ter povzemajo tudi nekatere mednarodne določbe o človekovih pravicah. Kljub temu pa veliko število teh držav še ni sprejelo oziroma ratificiralo obeh mednarodnih paktov o človekovih pravicah. Tiste muslimanske države, ki so to storile, pa jih dejansko $v$ praksi ne izvršujejo. To je posledica dejstva, da so številne takšne mednarodne določbe ne le $v$ nasprotju $z$ muslimanskim razumevanjem sveta ter posledično z muslimanskimi pogledi na zahodno doktrino človekovih pravic, temveč so $v$ nasprotju tudi z notranjim (šeriatskim) pravom teh držav (Ibidem v: Kuhar, 2007, str. 13).

Načelo enakosti je na zahodu osrednja vrednota pravnega reda (Perenič v: Kuhar, 2007, str. 15). To načelo je zapisano v 2. členu Splošne deklaracije o človekovih pravicah: "Vsakdo je upravičen do uživanja vseh pravic in svoboščin, ki so razglašene s to deklaracijo, ne glede na raso, barvo kože, spol, jezik, vero, politično ali drugo prepričanje, narodno ali socialno pripadnost, premoženje, rojstvo ali kakršnokoli drugo okoliščino. " Načelo enakega obravnavanja torej prepoveduje med drugim tudi diskriminacijo na podlagi spola. To pomeni izenačitev obravnavanja moških in žensk, zato je dejanske razlike med spoloma treba sprejemati kot nerelevantne (Franca v: Kuhar, 2007, str. 15).

Načelo komplementarnosti je islamska alternativa načelu enakosti $v$ delu, ki se nanaša na enakost med spoloma. Islamsko pravo $v$ celoti zavrača enakost med spoloma kot nekaj nenaravnega, saj moški in ženska ne moreta biti enaka, ne zavrača pa načelo enakopravnosti. Načelo komplementarnosti temelji na predpostavki, da je Bog moškega in žensko ustvaril različna. Kot taka imata tudi pripisane različne dolžnosti, ki so med seboj ostro ločene. Tukaj ni podana vrednostna sodba, ampak samo dejstvo, da sta si različna in le skupaj tvorita popolno celoto. Med spoloma pa ni nobene razlike, kar zadeva intelektualne sposobnosti, politično in družbeno udejanjanje. Položaj moškega in ženske $v$ islamskem pravu je določen predvsem glede na primarne biološke naloge obeh spolov. Moški kot vzdrževalec in zaščitnik družine, ženska pa kot mati in žena (Hoverić v: Kuhar, 2007, str. 15).

Islamsko pravo se imenuje šeriat, kar pomeni "jasna in od Boga začrtana pot«. Z verskega vidika to pomeni pot, ki se je morajo držati muslimani, če želijo doseči odrešitev. S pravnega vidika pa šeriat predstavlja skupek pravnih pravil, ki urejajo vsa področja človekovega delovanja (http://www.cfr. org/publication/8034/islam.html\#1 v: Kuhar, 2007, str. 8).

Šeriat je jedro islama. Brez znanja in razumevanja islamskega pravnega sistema ne moremo razumeti niti političnega sistema niti zgodovine razvoja 
družb, ki so sprejele islam (Feyzee, 1974, str. 16). Gre za pravo, ki je heteronomno, močno zakoreninjeno $v$ islamski veri in neločljivo povezano $s$ koranskoislamskim naukom o dolžnostih. Islam kot religija postave trdi, da s sto štirinajstimi božjimi razodetji, ki jih vsebuje Koran (sure) in jih je prek nadangela Gabrijela oznanil poslanec Mohamed, ureja vse življenje vernikov. To je torej nauk o dolžnostih, ki obsega tako verske in obredne predpise kot tudi družbenopolitična in pravna pravila. Neločljivo je urejen odnos človeka do boga ter odnos človeka do drugih članov skupnosti. $V$ islamskem pravu miselno ni prostora za zemeljskega zakonodajalca, ker je edini zakonodajalec Bog. Gre za zaprt sistem, ki ga teoretično ni več mogoče širiti ali dopolnjevati s kasnejšimi pravili ali določili z veljavo zakona (Grasmann in David, 1998, str. 486).

Pravo se $v$ islamu deli na pet temeljnih pravnih panog. Te so:

- ibidat, ki obravnava religiozna vprašanja,

- manakehat, ki je državno pravo v smislu funkcioniranja države,

- muamelat, ki se nanaša na medsebojne odnose,

- ukubat oziroma kazensko pravo in

- feraiz oziroma dedno pravo (Pavlica, 2004, str. 6.).

Čeprav šeriatsko pravo zahteva najprej izpolnjevanje dolžnosti, vsaka njegova norma še ne pomeni absolutne prepovedi oziroma zapovedi. $V$ določenih okoliščinah je namreč dopustno, da posameznik od nekaterih šeriatskih zahtev odstopi ali njihovo izvršitev preloži, dokler ne nastopijo pogoji, ob katerih norma postane izvršljiva.

V zvezi z izvrševanjem obveznosti razlikuje šeriatsko pravo pet zakonskih kategorij:

- stroga obveznost (fard in vadžib): izvrševanje teh dejanj se nagrajuje, opuščanje pa kaznuje (primer je dolžnost opravljanja molitev),

- stroga prepoved (haram): določena dejanja se ne smejo izvrševati, na primer tatvine in pitje alkohola,

- dovoljena dejanja (mubah): mogoče jih je izvrševati brez bojazni pred sankcijo in so popolnoma prepuščena volji posameznika (primer je udeležba na javni prireditvi),

- pohvalna dejanja: so priporočljiva (mandub) in vsakdanja zaželena dejanja (mustahab),

- zavržna dejanja (markuh): neko dejanje je neprimerno oziroma nemoralno, vendar ni kaznivo ( primer je »biti umazan «) (Kečanović v: Kuhar, 2007, str. 9). 
Alenka Kuhelj, Jasna Halilović

\section{Vloga in pomen islamskega prava}

$\checkmark$ današnjem času je tradicionalno šeriatsko pravo $v$ nekaterih islamskih državah še vedno del pozitivnega pravnega sistema. Prisotno je zlasti na področju osebnega statusa, ki ureja družinsko in dedno pravo, ter na področju pogodbenih razmerij (npr.darilnih pogodb in drugih neodplačnih ravnanj). Drugi pravni področji, kot sta kazensko in obligacijsko pravo, je večina islamskih držav modificirala z uporabo sekularne zakonodaje oziroma s sodobnejšo interpretacijo šeriatskega prava. Edini izjemi sta državi Iran in Savdska Arabija, ki imata še vedno v celoti uveljavljeno šeriatsko pravo (Ibidem v: Kuhar, 2007, str. 9).

Koran ne vsebuje pravil o veljavnosti islamskega prava. Norme islamskega prava se striktno in popolnoma nanašajo samo na pripadnike islama $v$ državah, ki so šeriatske. Islamsko pravo se omejeno uporablja tudi za muslimane, ki živijo na nemuslimanskem področju in le delno za nemuslimane na islamskem področju (Vilfan v: Prevolšek, 1989, str. 13). Ker je Koran sveta knjiga vseh muslimanov, zapovedi in prepovedi, priporočil in primerov, velja za vse vernike, ne glede na to, kje živijo. Torej lahko sklepamo, da tudi pravna pravila iz Korana veljajo za vse muslimane ne glede na teritorij, saj pravna pravila ne odražajo pravil državnih zakonodajnih organov (Prevolšek, 1989, str. 13).

Islamsko pravo je za muslimane rezultat božje volje in je zato nespremenljivo. Začetek veljavnosti je torej čas začetka islama oziroma čas objave Korana, konec veljavnosti pa je določen kot "sodni dan« (Prevolšek, 1989, str. 14).

\section{Viri islamskega prava}

\subsection{Razmerje med fikhom in šeriatom}

Večkrat se namesto izraza šeriat kot sinonim uporablja izraz fikh, čeprav je enačenje teh dveh pojmov nepravilno. Fikh (dobesedno inteligenca) je namreč jurisprudenčna znanost, ki poleg znanja (ilma) vsebuje tudi uporabo razuma ter neodvisne presoje. Definicija po klasični teoriji se glasi: "Fikh ali islamska pravna znanost je veda o posameznikovih pravicah in dolžnostih, ki izhajajo iz Korana, iz sune preroka, soglasja mnenj učenih (idžma) ali analogične dedukcije (kijas), " (Ibidem v: Česnik, 2001, str. 10) Razlika med fikhom in šeriatom je med drugim $v$ tem, da šeriat obravnava vsa človeška dejanja, fikh pa se ukvarja samo s pravnimi akti. Po fikhu so dejanja zakonita ali nezakonita, šeriat pa loči pet stopenj (ne)dovoljenosti. Fikh je pravna znanost, šeriat pa je pravo kot božje določena pot k pravičnosti (Česnik, 2001, str. 10). 


\subsection{Koran}

Koran je primarni vir islamskega prava, resnična beseda Boga in sveta knjiga muslimanov, ki vsebuje Alahovo razodetje, katerega je nadangel Gabrijel prenesel Mohamedu, da naj ga posreduje ljudem in pove, kaj je dovoljeno in kaj prepovedano. Pravila, ki so bila poslana od Boga, so najvišja, zato jih je treba vedno upoštevati. Vsakršen dvom o napisanem $v$ Koranu je zato nedopusten.

Koran je razdeljen na sto štirinajst sur - poglavij, ki se naprej delijo na ajet - odstavke (Grasmann in David v: Janžič, 2006, str. 11). Približno petsto verzov Korana vsebuje vse božje zapovedi, od katerih jih ima približno osemdeset pomen pravnih pravil (Afshar, 1999, str. 2).

Večji del verzov ima pomen reguliranja medsebojnih odnosov, kar pomeni, da je sam Koran mnogo bolj podroben, ko govori o veri in morali, kot pa o samih pravnih pravilih.

\subsection{Prevodi Korana}

Prevod Korana ni izvirno besedilo, ki je zapisano samo v arabskem jeziku in se zato $\vee$ arabščini tudi uporablja pri molitvi. Prevod tako nima nobenih pomembnejših lastnosti, ki se nanašajo na izvirnik. Ne more se uporabljati pri molitvi, edini pomen, ki ga ima, je, da bralcem, ki ne poznajo arabskega jezika, omogoči, da spoznajo njegovo vsebino. Prevod izgublja vrednost z vsako nadaljnjo interpretacijo in tako se vsak prevod prevoda oddaljuje od izvirnika. Pri prvem prevodu izvirnika sodelujejo vrhovni strokovnjaki, ki so poznavalci izvirnega besedila.

\subsection{Suna}

Suna je drugi najpomembnejši pravni vir. Vsebuje izročila (oziroma tradicijo), za katere ni izrecno zapisano, da so božanskega izvora. Gre torej za zapovedi, ki jih je treba izvrševati, ker jih je izvrševal ali priporočal ali pa samo odobril poslanec Mohamed in so kot take postale del njegovega izročila. Vse, kar je prerok Mohamed (kot božji poslanec) rekel, storil ali odobril, so kasneje zapisali v obliki hadisev, ki so del šeriatskega prava. Tisto, kar je rekel ali storil Mohamed kot človek, pa za muslimane ne pomeni obveznosti. 


\section{Alenka Kuhelj, Jasna Halilović \\ Vloga in pomen islamskega prava}

Pravniki tradicijo radi uporabljajo kot pripomoček za orientacijo pri delu in za dokazovanje pri obrazložitvah sodb. Suna je torej pravni vir, ki se uporablja za zapolnjevanje pravnih praznin (Grasmann in David v: Kuhar, 2007. str. 10).

\subsection{Idžma}

Idžma pomeni konsenz uglednih učenjakov (uleme, mudžtehidov, fakihov) o pomembnih verskih in pravnih vprašanjih, pri čemer ni potreben konsenz vseh muslimanov. Odločanje z idžmo je bilo prvotno dovoljeno le najožjim Mohamedovim kolegom. Kasneje se je ta pravica prenesla še na njegove učence (tabine) in na koncu še na druge izobražence, imenovane ulema (Ibid. v: Mišic, 2003, str. 8). V praksi so znani primeri, za katere odločitev $\vee$ Koranu ni bilo mogoče najti podlage, a je bilo odločitev vseeno treba sprejeti, pri čemer je odločilno vlogo odigrala idžma. Kljub temu, da idžmi islamski pravniki priznavajo šele tretje mesto med pravnimi viri, sodobni kritiki menijo, da je najpomembnejši element $v$ islamskem pravu, saj je pomemben dejavnik pri razvoju in prenovi šeriatskega prava. Tako je sistemu, ki je sam po sebi zaprt in usmerjen $\checkmark$ preteklost, omogočila nadaljnji razvoj na pravnem področju in nekako prevzela funkcijo naknadnega zakonodajalca (Mišič, 2003, str. 8).

\subsection{Kijas}

Kijas pomeni reševanje šeriatskega vprašanja, ki ni izrecno rešeno z obstoječimi pravnimi pravili $v$ besedilih Korana in sune (nas) s pomočjo analogije. Beseda kijas izvorno pomeni merjenje, sporazum, zgled in enakovreden. Namen kijasa je odkriti illah (ratio legis - smisel zakona), ki bi ga lahko nato razširili na podobne primere, ki niso pravno urejeni. Enako kot idžtihad (razumsko sklepanje), je tudi kijas zgolj postopek interpretacije virov islamskega prava, katerega namen je izpeljati določeno pravno pravilo. Pravne odločitve, sprejete s pomočjo postopka kijasa oziroma idžtihada, so na koncu le osebna mnenja, ki niso zavezujoča. Status splošnega pravila dobijo šele, ko so sprejeta z idžmo (Mumisa v: Trtnik, 2006, str. 6).

\section{Pravne šole}

Islamsko pravo se je oblikovalo skozi stoletja in šlo skozi različne procese razvoja. Posledica tega razvoja so različne interpretacije istih pravnih virov. Razumljivo je, da v času prerokovega življenja ni bilo potrebe po pravnih šolah, saj 
so se učenci v primeru dvoma glede kakšnega pravnega vprašanja lahko obrnili neposredno na Mohameda ali pa so se zgledovali po njem. Po smrti preroka in $\mathrm{s}$ šijenjem islama pa je nastala potreba po pravnih šolah, kjer so iskali odgovore na posamezna pravna vprašanja (Harcet v: Kuhar, 2007, str. 11).

Največje zasluge za kodifikacijo islamskega prava in njenega pravnega sistematiziranja pripadajo štirim velikim pravnim strokovnjakom. To so bili učeni možje, ki so ustanovili svoje dogmatično-pravne smeri in po katerih se imenujejo štiri najpomembnejše pravne šole (mezhebı). Islamsko pravo se torej razlikuje gleda na pravno šolo, ki je prevladujoča $v$ določeni državi. Vse štiri šole so danes enakopravne in se tudi medsebojno priznavajo. Te šole so (Grasmann in David v: Kuhar, 2007, str. 12):

- Hanefijska šola - ustanovitelj je bil pravni strokovnjak Abu Hanifa. Pri reševanju pravnih problemov so pripadniki te šole uporabljali metodologijo kijas. Metodologija njihovega dela temelji na sistemu, ki pravne rešitve išče najprej v Koranu, če jih tam ne najde, pa uporabi še druge pravne vire. Druga pravna osnova je suna (tradicija), tretja mišljenje Mohamedovih sodelavcev in nazadnje lastno razmišljanje. Njegova šola je znana po racionalistični usmeritvi. Hanefijski šoli pripadajo zlasti muslimani iz Turčije, območja nekdanje Jugoslavije, Afganistana, Pakistana, Kitajske, Indije, Iraka kot tudi iz dela Egipta in Arabskega polotoka (Nasir v: Kuhar, 2007, str. 12).

- Malikijska šola, ki jo je ustanovil Malik Ibn Enes. Metodologija njihovega dela je utemeljena predvsem na iskanju opore $\vee$ Koranu, če rešitve ne najde tam, jo poišče $v$ suni. Velik pomen pripisuje predvsem tradiciji. Malikijski šoli pripadajo muslimani $\vee$ severni in zahodni Afriki (Bećirović v: Kuhar, 2007, str. 12).

- Šafijska šola, ki jo je ustanovil Al-Shafii. Pri svojem delu združuje vplive hanefijske in malikijske šole. Za reševanje pravnih vprašanj uporablja racionalistični in tradicionalistični pristop. Rešitve išče predvsem v Koranu in suni. Šafijski muslimani živijo predvsem na območju južnega arabskega polotoka, vzhodne Afrike, Malezije, Tajske, Šri Lanke in Maldivov (Ibidem v: Kuhar, 2007, str. 12).

- Hanbelijska šola, ki jo je ustanovil Ahmed Ibn Hanbel. Njihova metodologija temelji predvsem na Koranu in suni. Pri šeriatskih pravnih rešitvah daje prednost suni pred analogijo. Danes živijo hanbelijski muslimani predvsem $v$ Savdski Arabiji (Ibidem v: Kuhar, 2007, str. 11).

Na podlagi dela štirih pravnih strokovnjakov in njihovih učencev je nastalo šeriatsko pravo, kot ga poznamo danes. Posamezna odstopanja, kot so omenjena zgoraj, so nastala kot posledica različnih interpretacij istega besedila. Nekateri so 
Alenka Kuhelj, Jasna Halilović

Vloga in pomen islamskega prava

besedila razumeli bolj dobesedno, drugi manj. Vse štiri šole se med seboj priznavajo, zato lahko vsak musliman spremeni pripadnost šoli po svojem prepričanju. Pravni posli se sklepajo po predpisih katerekoli šole, sodniki pa rešujejo spore po predpisih določene šole (http://www.cfr.org/publication /8034/islam.html\#1 v: Kuhar, 2007, str. 13).

\section{Institut zakonske zveze $v$ islamskem pravu}

Islamska zakonska zveza je definirana kot pogodba civilnega prava. Gre za sporazum o življenjski skupnosti dveh oseb različnega spola s svobodno voljo obeh oseb ter ob prisotnosti dveh prič z namenom oblikovanja družine. Njena cilja sta ohranjanje morale in reprodukcija človeške vrste. Bistvo pogodbe je torej legalizacija intimnega življenja mladoporočencev in rojstvo otrok. Sklenitev zakonske zveze ni zakrament, kot ga pozna krščanska vera, ampak samo konsenz bodočih zakoncev. Poroka je za vsakega muslimana dolžnost, razen za tiste, ki ne bi mogli izpolnjevati zakonskih dolžnosti (Sedgwick v: Kuhar, 2007, str. 21).

Zakonska zveza mora biti sklenjena $v$ skladu s šeriatskimi pravili, ker je sicer neveljavna. Pogoji veljavnosti so:

1. svobodna izjava volje obeh strank

Soglasje lahko podata stranki sami ali njuna zastopnika, če sta obe stranki sposobni za sklenitev zakonske zveze. To pomeni, da morata biti polnoletna in duševno zdrava (Grasmann in David v: Kuhar, 2007, str. 22).

\section{2. razsodnost obeh strank}

Obe stranki morata biti razsodni. $\vee$ primeru, da je ena stranka mladoletna ali sta obe mladoletni oziroma duševno bolni, so njuni skrbniki tisti, ki lahko v imenu svojega varovanca (varovanke) sklenejo veljavno zakonsko zvezo (Ibidem v: Kuhar; 2007, str. 22).

3. ponudba in sprejem ponudbe

Ustna izjava ponudbe in njen sprejem morata biti izjavljena istočasno in na istem kraju. Razlog je nedvoumnost sklenitve zakonske zveze. Ponudba je lahko dana tudi v pisni obliki, če je ponudnik odsoten, vendar se mora na glas prebrati nasprotni stranki in pričam (Haverić v: Kuhar, 2007, str. 22).

4. odsotnost zakonskih ovir

Pri sklenitvi zakonske zveze ne smejo biti podane zakonske ovire. Te ovire so krvno sorodstvo, sorodstvo po mleku, sorodstvo, ki nastane s poroko, trikrat 
izgovorjena namera razveze, pozakonsko čakanje, začasne motnje ter druge (Kuhar, 2007, str. 22).

Zakonske ovire so začasnega ali trajnega pomena. Dokler so podane, zakonska zveza med moškim in žensko ni mogoča. Te ovire so (Kuhar, 2007, str. 22):

a) krvno sorodstvo;

Po šeriatskem pravu je zakonska zveza med krvnimi sorodniki strogo prepovedana. Muslimani se ne smejo poročiti s svojo materjo, staro materjo, hčerjo, sestro, sestrično, vnukinjo in njenim potomstvom in teto po očetovi in materini strani (Haverić v: Kuhar, 2007, str. 24).

b) sorodstvo po mleku

Gre za sorodstvo, ki je izenačeno s krvnim sorodstvom. Nastane med dojiljo in tujim otrokom, mlajšim od dveh let, ki ga ona doji s svojim mlekom. Otrok se smatra za prvorojenca svoje dojilje. Zaradi tega se ne sme poročiti s tistimi sorodniki svoje matere po mleku, s katerimi se ne sme poročiti prvi otrok dojilje (Ibidem v. Kuhar, 2007, str. 24).

c) sorodstvo, ki nastane s poroko

Prepovedana je zakonska zveza muslimana s svojo taščo, taščino mamo, taščino mačeho, sinovo snaho, ali s snahami njegovih potomcev in pastorko (Ibidem v: Kuhar, 2007, str. 24).

č) trikrat izgovorjena namera razveze;

Kadar mož jasno in glasno pove svoji ženi, da se od nje ločuje, se taka zakonska zveza šteje za razvezano. Nadaljnje skupno življenje se šteje za zunajzakonsko. $\vee$ primeru trikratne take razveze pa se mož ne more ponovno poročiti z njo, dokler se ona ne poroči z drugim moškim, se nato od njega loči ali postane vdova ter po izteku njenega pozakonskega čakanja (Nasir v: Kuhar, 2007, str. 24).

d) pozakonsko čakanje

Po šeriatskem pravu ni dovoljena sklenitev zakonske zveze z žensko, ki se nahaja $v$ obdobju svojega pozakonskega čakanja. Gre za obdobje po razvezi oziroma smrti moža. Namen tega obdobja je $\vee$ odpravi dvoma očetovstva, če je ženska noseča. Kadar ni noseča, traja tri mesece, če je noseča, traja do rojstva otroka, $v$ primeru smrti moža pa traja štiri mesece in deset dni (Smailagić v: Kuhar, 2007, str. 25).

e) druge ovire

Nekateri islamski pravniki priznavajo med ovire tudi nepoznavanje islamskih načel, revščino, družbeno neenakost in prepoved sklenitve zakonske zveze muslimanke z nemuslimanom (Haverić v: Kuhar, 2007, str. 25). 


\section{Alenka Kuhelj, Jasna Halilović \\ Vloga in pomen islamskega prava}

\section{5. prisotnost dveh prič}

Soglasje mora biti podano ob navzočnosti dveh prič moškega spola. Eno moško pričo lahko nadomestita dve ženski. To zahtevo utemeljujejo muslimani na dejstvu, da so ženske bolj čustveno prisotne pri določenih življenjskih primerih in s tem tudi bolj "pozabljive«. Poleg tega morajo biti priče polnoletne, razsodne, pripadnice islamske vere ter sposobne slišati in razumeti izjavo.

\section{6. poznavanje osnovnih islamskih principov}

Bodoča zakonca morata znati sama izgovoriti in s svojim besedami opisati bistvo islamskega verovanja (Kuhar, 2007, str. 23).

Pogodba o zakonski zvezi je veljavna in zavezujoča, če je v skladu z zgoraj navedenimi načeli in torej $s$ šeriatskimi predpisi. Zlasti pomembni so pogoji veljavnosti in zakonske ovire. $\vee$ pogodbi se zakonca dogovorita o medsebojnih pravicah in dolžnostih ter o morebitnih posebnostih glede samega zakona. Vendar sporazum ne sme biti v nasprotju s strogimi predpisi šeriatskega prava, saj je drugače neveljaven. Pogodba je zlasti pomembna za položaj ženske $v$ zakonski zvezi. Kadar je ženska oziroma njen skrbnik (vall) pogajalsko sposobnejši, si lahko zagotovi številne pravice, ki jih sicer ne bi imela. Sporazum lahko vsebuje na primer določbo, da ima ženska pravico do razveze, če bo mož sklenil novo zakonsko zvezo. S tem lahko omeji moževo poligamijo. Bistvena sestavina sporazuma je tudi dogovor o višini, vsebini in načinu plačila poročnega darila (mehr), ki ga mož izroči svoji ženi (Nasir v: Kuhar, 2007, str. 25). Mehr je poročno darilo, ki ga mož obljubi svoji bodoči ženi $\vee$ pogodbi o zakonski zvezi. Ženi lahko izroči denar, zlato ali druge predmete, ki imajo premoženjsko vrednost. Običajno se del poročnega darila izroči ob sklenitvi zakonske zveze, preostali del pa ob razvezi ali smrti moža. Ženska lahko preostali del darila zahteva šele, ko je zakonska zveza sklenjena. Kadar pride prej do razveze, lahko žena zahteva samo polovico darila. Ženska s svojim poročnim darilom prosto razpolaga, kar pomeni njeno finančno in ekonomsko neodvisnost (Sedgwick v: Kuhar, 2007, str. 26).

Preživljanje je zakonita pravica žene na podlagi veljavne pogodbe o sklenitvi zakonske zveze. Pravica ji pripada le, če izpolnjuje svoje zakonske dolžnosti. Mož je dolžan zagotavljati sredstva skladno s svojimi sposobnostmi za bivališče, hrano, obleke in druge gospodinjske potrebščine (Nasir v: Kuhar, 2007, str. 27). 
$\checkmark$ šeriatskem pravu pa ne poznajo instituta skupnega premoženja moža in žene, ampak ima vsak zakonec svoje premoženje. Žena obdrži popolno svobodo glede razpolaganja s svojim premoženjem. Izjemoma lahko mož uživa in upravlja ženino premoženje, a le kadar ga je sama pooblastila. Vendar mož odgovarja, če ji s svojimi dejanji povzroči škodo. Kadar pride med zakoncema do spora glede premoženja, velja, da so vse stvari, ki jih uporablja izključno žena, njene. Vse preostale stvari pripadajo možu ali pa so skupna last obeh zakoncev (Ibidem v: Kuhar, 2007, str. 27).

Pravice in dolžnosti zakoncev so $v$ skladu $z$ načelom komplementarnosti natančno določene in ostro ločene (Kuhar, 2007, str. 27).

\section{Pravice moža $\vee$ zakonskem razmerju:}

a. ženo opozarja na osebno higieno, če ji ta ne posveča dovolj pozornosti, vztrajanje pri dostojnem oblačenju soproge,

b. pravica do spolnih odnosov, razen $\vee$ primeru šeriatskih prepovedi (zdravstveni in drugi razlogi), ko ima žena pravico moža zavrniti,

c. od žene zahteva, da brez razloga in šeriatskega opravičila ne zanemarja islamskih dolžnosti, kot so molitev, post in podobno,

d. mož ne dopušča ženi, da ponižuje in obklada z žaljivimi vzdevki njega, njegove starše, sorodnike in prijatelje,

e. opozarja ženo, če ta ne izpolnjuje dolžnosti, ki jih je kot žena in mati dolžna izvrševati.

\section{Dolžnosti moža v zakonu:}

a. vzdrževati svojo ženo in to po svojih materialnih zmožnostih,

b. vnaprej predati ženi dogovorjeno poročno darilo,

c. lepo in korektno ravnati s soprogo, saj je to eden od najpomembnejših pogojev za srečen zakonski odnos,

d. varovati in spoštovati ženino dostojanstvo,

e. sodelovati pri pravilni vzgoji otrok,

f. ceniti in spoštovati ženino sorodstvo.

\section{Pravice žene v zakonski zvezi:}

a. samostojno razpolaga s svojim imetjem,

b. obiskuje svoje starše,

c. obiskuje bližnje in daljno sorodstvo, kot so bratje, sestre, sestrične in bratranci,

d. se izobražuje in moralno dograjuje po načelih islama,

e. opravi romanje $v$ Meko, če je to možno, 
Alenka Kuhelj, Jasna Halilović

\section{Vloga in pomen islamskega prava}

f. odreče poslušnost možu, če ta od nje zahteva nekaj, kar je v nasprotju s šeriatskimi predpisi.

\section{Dolžnosti žene v zakonski zvezi:}

a. varuje avtoriteto, čast in dostojanstvo svojega moža,

b. dovoli mu intimni odnos, če ni upravičenega razloga ali šeriatske ovire, kakor sta nosečnost in menstruacija,

c. ne ravna razsipno s premoženjem, pridobljenim skupaj ali od enega od zakoncev,

d. vestno opravlja naloge, ki jih ima kot žena in mati,

e. varuje potomstvo svojega moža in sodeluje pri vzgoji otrok.

\section{Skupne dolžnosti zakonskih partnerjev:}

a. medsebojna ljubezen in vzajemno spoštovanje,

b. skrb za otroke in vzgoja,

c. vzajemno spoštovanje družine.

(http://www.eporoka.com/sl/cerkvenaporoka/ISLAMSKASKUPNOST-

ZAJEDNICA $」$.)

Šeriatsko pravo dovoljuje zakonsko zvezo med muslimanom in nemuslimanko. Edina omejitev je, da mora biti pripadnica krščanske ali judovske vere. Razlog za to določbo je dejstvo, da muslimani za sebi enake štejejo le pripadnike monoteističnih verstev. $V$ versko mešanem zakonu ženi ni potrebno prestopiti $v$ islam. Mož ji ne sme prepovedati izvrševanja njenih verskih obredov. Zakonska zveza s pripadnico politeističnega verstva, na primer hindujko, je dopustna le, če ženska pred poroko prestopi $v$ islam. Poroka $z$ ateistko je prepovedana. Otroci, rojeni $v$ versko mešanem zakonu, so avtomatično muslimani, ker moževa vera prevlada nad ženino. Žena, ki ni muslimanka, je $v$ slabšem položaju kot muslimanka, ker nima pravice do zakonitega dedovanja po svojem možu. Deduje lahko le na podlagi veljavne oporoke, vendar delež ne sme presegati ene tretjine celotne zapuščine (Sedgwick v: Kuhar, 2007, str. 30).

Po drugi strani pa je zakonska zveza muslimanke z nemuslimanom prepovedana. Pogodba o taki zakonski zvezi je nična. Muslimani utemeljujejo to prepoved z dejstvom, da $v$ mešani zakonski zvezi moževa vera prevlada nad ženino. Muslimanka ne bi mogla izvrševati svojih verskih obredov in dolžnosti, kar je za muslimane nesprejemljivo. Muslimani menijo, da je neprimerno, da muslimanka rojeva in vzgaja pripadnike drugih ver (Nasir v: Kuhar, 2007, str. 30).

Poligamija ali mnogoženstvo ni institut, ki ga je uvedla islamska vera, saj je obstajala že pred nastankom te vere na območju arabskega polotoka in tudi 
drugje. Moškemu je poligamija dovoljevala neomejeno število žena. Islam tega običaja ni prekinil, vendar ga je omejil na največ štiri žene (Ibidem v: Kuhar, 2007, str. 32).

Zagovorniki poligamije utemeljujejo njeno nujnost na podlagi tako imenovanih življenjskih dejstev. Argument vidijo $v$ vojnah, $v$ katerih naj bi umrlo veliko število moških, zaradi česar za njimi ostane veliko nepreskrbljenih vdov in sirot. Moški naj bi torej poročil več žensk in jim s tem zagotovil zaščito. Musliman ima lahko štiri žene, vendar je zaželeno, da za sklenitev druge, tretje ali četrte zakonske zveze praviloma pridobi soglasje prve žene, res pa je, da ga a priori ne potrebuje, niti ne potrebuje dovoljenje sodišča. Vse žene imajo status zakonske žene z enakimi pravicami in obveznostmi. Mož mora vsaki izmed njih zagotoviti ločeno bivališče in z vsemi mora enako ravnati. Vse žene in njihove otroke mora preživljati. Otroci, rojeni v taki zvezi, se štejejo za zakonite otroke svojih staršev (Sedgwick v: Kuhar, 2007, str. 33).

Kljub vsemu imajo ženske možnost omejitve moževe poligamije. To lahko storijo $z$ določbo $\vee$ pogodbi $\vee$ zakonski zvezi. $\vee$ pogodbo se lahko doda tudi pogoj, da ima žena pravico do razveze, če mož sklene novo zakonsko zvezo brez njenega soglasja (Nasir v: Kuhar, 2007, str. 33).

$\checkmark$ današnjih časih je poligamija $\vee$ zatonu. Več žena namreč je za moža večji finančni zalogaj kot pa samo ena. To pomeni, da je poligamija privilegij zlasti bogatih muslimanov. Samo okoli deset odstotkov vseh zakonov $v$ arabskih državah je poligamnih. Poligamija je dandanes s pozitivno zakonodajo prepovedana $\vee$ državah, kot so Turčija, Tunizija, Etiopija in v drugih. V Alžiriji, Maroku, Indoneziji in drugih državah pa je zakonodajalec določil strožje pogoje za moža, če želi imeti več kot eno ženo. Pogoja sta dovoljenje sodišča in soglasje obstoječe žene. Žena pa ima pravico zahtevati razvezo zakonske zveze, če zaradi nove žene trpi škodo ali pa za sklenitev novih zvez ni podala soglasja (Harcet v: Kuhar, 2007, str. 33).

Šeriatsko pravo natančno določa tudi pogoje in način, na podlagi katerih je mogoča razveza zakonske zveze. Razveza naj bi bila bolj izjema kot pravilo, zato Islam spodbuja zakonca, da pred ločitvijo poizkusita razrešiti medsebojna nesoglasja. Razveza je dovoljena, a le kot skrajna možnost rešitve nevzdržnega skupnega življenja. Šeriatski pravniki so mnenja, da je razveza manjše zlo od tistega, ki ga povzroča nesrečen zakon. Ta ima lahko negativen vpliv na celotno islamsko skupnost. Menijo, da vsak zakon ni nujno harmoničen, zato prepoved razveze ni naravna, niti ne odgovarja naravi ljudi (Handzić v: Kuhar, 2007, str. 38). 


\section{Alenka Kuhelj, Jasna Halilović \\ Vloga in pomen islamskega prava}

\section{Zakrivanje žensk}

Zakrivanje žensk ni islamskega izvora. To so počeli že predislamski Arabci, ker so želeli svoje ženske zaščititi pred pogledi tujcev, potencialnih sovražnikov. $\checkmark$ tistih časih so bili različni napadi, ugrabitve in posilstva stalno prežeča nevarnost (Harcet v: Kuhar, 2007, str. 48). Islamska vera tradicije zakrivanja žensk z naglavnimi rutami (hijab) ni prekinila, ampak jo torej samo nadaljuje (Ibidem v: Kuhar, 2007, str. 48). Islamski komentatorji Korana se strinjajo, da mora ženska svoje telo pokriti in da njena obleka in hoja ne smeta povzročati pozornosti, kadar je $v$ navzočnosti osebe nasprotnega spola, ki ni bližnji družinski član. Islam določa "spodnjo mejo« dovoljenega pri oblačenju, ki jo ženske ne smejo prekoračiti, drugo pa prepušča svobodni izbiri, okoliščinam in finančnim sposobnostim posameznice. Pravila oblačenja so sicer določena tako za moške kot za ženske, vendar so pravila ženskega oblačenja veliko bolj kontroverzna (Kuhar, 2007, str. 48). V Koranu je zapisano: "Vernicam reci, naj hodijo s spuščenim pogledom in naj pazijo na svoje sramne dele. Naj ne dovolijo, da bi se videlo, kaj od njihovega okrasja - razen tistega, kar je tako ali tako zunaj. Tančice naj imajo čez prsi, svojega okrasja pa naj ne kažejo naokrog... O, glasnik vere! Reci svojim ženam, svojim hčeram in ženam vernikov, naj se dostojno oblačijo. Tako bodo prepoznane, nihče pa jih ne bo nadlegoval." (Koran v: Kuhar, 2007, str. 48, 49).

Po eni izmed najbolj strogih interpretacij Korana se v skladu z zgoraj navedenim besedilom lahko vidijo samo ženski obraz, dlani in stopala, ker so tako ali tako zunaj. Nekateri islamski interpretatorji menijo, da je tudi obraz del ženskega okrasja in naj bo zato prekrit. Oblačila ne smejo biti prozorna in oprijeta. Skromnost, dostojnost in neizzivalnost naj bi bila torej glavno vodilo pri oblačenju muslimanskih žensk (http://mwlusa.org/topics/dress/hijab.html v: Kuhar, 2007, str. 49).

Islam dejansko ne določa konkretnega načina oblačenja, zato se način zakrivanja razlikuje od države do države (oziroma pravilneje od ženske do ženske). Način zakrivanja žensk je še najbolj odvisen od lokalnih običajev. Ženske se zakrivajo na najrazličnejše načine ali pa sploh ne. Nekatere nosijo samo naglavno ruto, druge tudi ohlapne obleke, ki prekrivajo celo telo razen obraza, tretje pa zakrivajo tudi svoj obraz.

$\checkmark$ Egiptu, na primer, tradicionalne muslimanke nosijo dolge ohlapne obleke, glave pa si zakrivajo z naglavnimi rutami. V Iranu in Savdski Arabiji pa je celo s kazenskima zakonoma določeno obvezno nošenje naglavne rute tako za 
pripadnice islama kot tudi za druge ženske. Sankcija je zaporna kazen v razponu od deset dni do dveh mesecev (Minces v: Kuhar, 2007, str. 49).

Obvezno zakrivanje žensk je po mnenju sunitskih in šiitskih pravnih šol le verska dolžnost vsake muslimanke. Islamsko pravo na splošno ne določa kaznovanja žensk, ki se ne zakrivajo (http://mwlusa.org/topics/dress/hijab.html v: Kuhar, 2007, str. 49).

$V$ današnjem času lahko opazimo dva nasprotujoča si trenda zakrivanja žensk. Po eni strani upada zakrivanje žensk kot posledica večje izobraženosti, zaposlovanja in udeleževanja žensk $v$ javnem življenju. Po drugi stani pa se pojavlja trend povečevanja zakrivanja žensk iz političnih razlogov.

Edini islamski državi, ki prepovedujeta nošnjo hijaba $\vee$ državnih organih, šolah in univerzah, sta Turčija (ki je dejansko sekularna republika) in Tunizija (Minces v: Kuhar, 2007, str. 50).

\subsection{Primer nošenja naglavnih rut v Turčiji}

Evropsko sodišče za človekove pravice je 29. junija 2004 z odločbo v zadevi Leyla Sahin proti Turčiji odločilo, da tožena država s prepovedjo nošenja naglavne rute na državnih univerzah ni kršila določila 9. člena Evropske konvencije o človekovih pravicah (svoboda misli, vesti in veroizpovedi). Država je s prepovedjo želela zavarovati pravice in svoboščine drugih posameznikov ter ohraniti javno varnost in zavarovati javni red, to pa so legitimni interesi, ki jih je sodišče štelo za upravičene pri posegu države $v$ pravico pritožnice do izražanja vere. Turčija je sekularna republika, ki spoštuje ustavno načelo laičnosti države. Čeprav je 99 \% prebivalcev muslimanov, država omejuje pravico do izpovedovanja vere $v$ javnih ustanovah, vladnih uradih ter šolah in univerzah. Vlada je prepovedala nošenje muslimanskih rut javnim uslužbenkam, torej tudi učiteljicam in predavateljicam na univerzah. Študentke, ki nosijo rute, ne smejo obiskovati predavanj. Rute so prav tako prepovedane na sodiščih. Prepoved nošenja religioznih oblačil $v$ javnem življenju $v$ Turčiji ni novost. Posledica družbenih sprememb $v$ turški družbi z začetka 20. stoletja je bil zakon o nošenju pokrival, ki je začel veljati leta 1925 in je uvedel nošenje sodobnih oblačil. Že leta 1934 je bil sprejet zakon o ureditvi nošenja oblačil. Prepovedal je oblačila, ki izražajo versko pripadnost na vseh javnih mestih, ki niso povezana z molitvijo in drugimi verskimi obredi. Iz istega razloga, kot je država prepovedala nošenje religioznih oblačil $\vee$ javnem življenju, je posegla tudi v izobraževanje. Z zakonom o izobraževanju je leta 1924 odpravila zasebne verske šole in uvedla 
Alenka Kuhelj, Jasna Halilović

Vloga in pomen islamskega prava

enoten sistem javnega šolstva. Z zakonom iz leta 1981 pa je posebej prepovedala nošenje oblačil, ki izražajo versko pripadnost $v$ visokošolskih izobraževalnih ustanovah. Zakon je za zaposlene in za študente predpisal nošenje sodobnih oblačil. Posebej je bilo poudarjeno, da je nošenje rut v izobraževalnih ustanovah prepovedano. Najvišja turška sodišča so utemeljenost prepovedi nošenja rut obrazložila s stališčem, da je versko pogojeno zakrivanje las in vratu z ruto $v$ nasprotju z načeli sekularizma in enakosti. Turško politiko prepovedi muslimanske rute je s prej navedenim primerom Leyla Sahin proti Turčiji podprlo tudi Evropsko sodišče za človekove pravice v Strasbourgu (Kuhelj, 2004, str. 40).

\subsection{Primer (problem) nošenja pokrival v javnih šolah v Franciji}

Francija je $v$ zadnjih letih oblikovala svojevrstno politiko reševanja vprašanj, ki so povezana z nošenjem verskih simbolov. Z zakonom 2004-228 z dne 15. marca 2004 so Francozi prepovedali nošenje naglavne rute, katoliškega križa in judovske čepice ter drugih verskih simbolov $v$ javnih šolah, $s$ tem, da je pomembno poudariti, da ruta kot taka ni verski simbol, ampak je kot pokrivalo $\mathrm{v}$ širšem pomenu zapovedano. Za spremembo in primerjavo, $v$ nobeni verski knjigi križ ni zapovedan kot del obveznega oblačenja vernika. Prepoved se nanaša na vse verske simbole, ki zbujajo pozornost, ki so več kot opazni oziroma očitni, pri čemer zakon ne omenja nobenega simbola posebej, čeprav je iz družbenega in političnega konteksta jasno in očitno, da se prepoved nanaša še posebej na nošenje naglavnih rut $v$ šolah. Francija je $s$ sprejetjem zakona želela formalno zavarovati dosledno izpeljani sekularizem $v$ javnem šolstvu in po svoje prisiliti muslimanske učenke, da prevzamejo evropski način oblačenja.

Vlada je končno udejanjanje prepovedi nošenja očitnih verskih simbolov prepustila samim izobraževalnim ustanovam, tako da te lahko dovoljujejo nošenje majhnih rut (bandane), ki so danes modni dodatek številnih deklet po svetu. Čeprav je Francija s prepovedjo verskih simbolov zahodnemu svetu želela sporočiti, da se zavzema za enakost spolov oziroma emancipacijo žensk in idejo modernizacije, pa je sporočilo precej »mlačno« (Kuhelj, 2004, str. 41).

\section{Kazensko pravo}

Za razumevanje islamskega kaznovalnega sistema (ukubat) moramo najprej razumeti njegovo mesto znotraj islamskega pravnega okvira kot celote oziroma znotraj samega islama. Islam vzpostavlja popoln sistem in regulira vse vidike 
človekovega življenja. Filozofija kaznovanja je integralni del sistema, ki ga ne moremo razumeti drugače kot znotraj njenih načel, ki imajo namen varovati temeljne vrednote islama, ki se predvsem seštevajo $v$ osnovah, kot so upreti se zlu in propadu posameznika in s tem posledično celotne družbe. Dovoljena dela (halali) in prepovedana dela (harami), ki ju srečujemo $v$ sferi islamske zakonodaje oziroma šeriata, imajo osnovni cilj, ki je nuditi srečo in dobro ljudem ter jih hkrati zaščititi pred bremeni in s tem povezanim težkim življenjem. Da bi bilo ljudem lažje, je vodilo $v$ islamu, za katerega tudi Bog pravi, da naj se ne bremeni človeka prek njegovih zmožnosti. Od tu ta imperativ, da je potrebno vse slabo in negativno umakniti iz življenja vernikov, saj bo to koristilo tako duši kot tudi telesu, umu in človeštvu.

Vire islamskega kazenskega prava lahko delimo na primarne in sekundarne. Primarni viri Korana in suna temeljijo na prej obstajajočih besedilih, sekundarni pa temeljijo "na intelektualnem naporu«, da se odkrije pravno pravilo (Belal v: Mišic, 2003, str. 13). Tako je ustava najpomembnejši sekundarni vir kazenskega prava $v$ islamskih državah. Iz teh ustav izhaja, da sta Koran in suna temeljna vira prava in da mora biti kazensko pravo $v$ skladu $z$ njunimi prepovedmi (Mišic, 2003, str. 14).

\subsection{Kazniva dejanja}

Kaznivo dejanje je po islamskem pravu vsakršno dejanje, ki je prepovedano po šeriatu. Kaznivo dejanje je $v$ islamu zelo resen moralni problem in je tako tesno povezan z mirom in harmonijo družbenega življenja (http://www. brudirect.com/criminal/part1.htm v: Mišic, 2003, str. 15). Na splošno so kazniva dejanja povezana z grehom, kar pomeni, da kršijo tudi moralne norme. Morala v islamskem pravu ni utemeljena s konkretno določitvijo kaj je dobro in kaj je slabo, kaj je humano in kaj nehumano. Alah kot najvišji zakonodajalec sporoča vernikom, kaj je moralno oziroma nemoralno. Ohranjanje morale, ki temelji na religioznih normah, je primarna dolžnost islamske države (Mišic, 2003, str. 16).

$\checkmark$ islamskem pravu se kaznivo dejanje definira kot storitev prepovedanega ravnanja ali opustitev zapovedane dolžnosti (Sanad v: Mišic, 2003, str. 17). Islamsko pravo je namreč uporabljeno kot instrument moraliziranja in kot agent preprečevanja, kar doseže z uporabo številnih metod, na primer s svarilom ljudi o zemeljski ter božji kazni, ki bo sledila po smrti (lbid. v: Mišic, 2003, str. 17). 
Alenka Kuhelj, Jasna Halilović

\section{Vloga in pomen islamskega prava}

\subsection{Vrste kazenskih sankcij}

Po načinu odrejanja kazni, pozna šeriatsko pravo tri vrste kaznivih dejanj (Imamović, 2005, str. 99):

\subsubsection{Hudud}

Kazni hudud se izrekajo za najresnejša kazniva dejanja, storjena zoper javni interes. Določene so s šeriatom. Pojmujejo se tudi kot kazniva dejanja zoper Alahovo pravico. Ti zločini se $v$ islamski pravni teoriji razumejo kot nespremenljive božje zapovedi, saj želijo zavarovati javni interes in vrednote, kot so lastnina, varnost, družinske vrednote, potomstvo in osebni ugled $v$ skupnosti (Mahmoudi v: Mišic, 2003, str. 32). Pregon takšnih kaznivih dejanj je obvezen in nujen, kazen pa mora biti izrečena in izvršena na način, kot je predvideno $v$ Koranu in suni. Ko je krivda dokazana, nihče ne more zvišati, znižati ali odpustiti kazni. Vendar $v$ primeru, če žrtev ali njen skrbnik storilcu kaznivega dejanja odpustita, $v$ veliki večini kaznivih dejanj hudud, na primer pri kraji, kazenska sankcija ne bo izrečena. $V$ tem primeru bo sodnik določil alternativno kazen (tazir) (Ibid. v: Mišic, 2003, str. 32). Enako se zgodi, če se storilec pokori za svoje grehe pred pričetkom kazenskopravnega pregona oziroma vsaj preden se njegova krivda dokaže pred sodiščem (Mišic, 2003, str. 32).

Fikh definira hudud tudi kot zločin, za katerega so kazni znane s pomočjo neizpodbitnih dokazov, ki so predvideni že $v$ Koranu in suni (Motzki v: Mišic, 2003, str. 32). Pojem hudud tako pomeni nespremenljivo omejitev, pri čemer je omejitev dana od Boga za celo islamsko družbo (Ibid. v: Mišic, 2003, str. 32). Vsaka posamična obsodba in izrečena kazen sta božji obsodbi, zato sta objektivni in nespremenljivi za vsakogar. Pri izrekanju in izvrševanju kazni hudud ni nikakršnega odpuščanja. Tako ne sodnik ne vladar nimata avtoritete za pomilostitev storilca. Kazen je preprosto treba izvršiti (Mišic, 2003, str. 32).

Med kazniva dejanja, ki se kaznujejo s kaznimi hudud, islamski pravniki uvrščajo zlasti: prešuštvo (zina), neutemeljeno obtožbo prešuštva (kazf), krajo (sirkat), rop (hirabah), pitje alkohola (šurb) in odpadništvo od vere (murted) (www.info-nyazee.com v: Mišic, 2003, str. 32).

a) Prešuštvo (zina)

Prešuštvo je prostovoljno spolno občevanje s katerokoli drugo osebo ne glede na to, ali je prešuštnik ali prešuštnica poročen(a) ali ne. Če se dokaže, da je človek prešuštvoval, je kazensko odgovoren. Če je poročen, zasluži kazen kamenjanja do smrti. Če ni poročen, ga čaka kazen stotih udarcev z bičem. 
Kaznovanje je javno (Ibid. v: Mišic, 2003, str. 33). Koran določa: „Prešuštniku in prešuštnici, vsakemu izmed njih pripada kazen sto udarcev z bičem. Ne imejte milosti z njimi v izvrševanju božje odredbe, če verjamete $v$ Boga in Sodni dan. Izvrševanju kazni mora prisostvovati skupina muslimanov. "Kazen, ki je predpisana v Koranu, je bičanje (sto udarcev) (Koran v: Prevolšek, 1989, str. 24). Prešuštvovanje se mora po šeriatu dokazati, in sicer s potrditvijo štirih zaupanja vrednih oseb, da so točno določeno dejanje tudi videle. Enak učinek je dosežen tudi, če ena sama oseba štirikrat potrdi, da je videla dejanje.

b) Neutemeljena obtožba prešuštva (kazf)

Islamsko pravo pa ne kaznuje le prešuštva. Kazniva je tudi že neutemeljena obtožba prešuštva. Do tega pride, kadar tožniku ne uspe pripeljati štirih prič, ki so potrebne za pričanje o prešuštvu. Tožnika $v$ tem primeru doleti kazen osemdesetih udarcev z bičem. To pa ni edina kazen. Obsojena oseba namreč izgubi tudi "status " zaupanja vredne osebe in se njenih izpovedb ne sme več nikjer in nikoli upoštevati (Sanad v: Mišic, 2003, str. 33).

c) Kraja

Krajo islamsko pravo definira kot dejanje, ko storilec vzame tujo premičnino brez dovoljenja lastnika, z namenom, da si to stvar prilasti. Kazen za krajo je sekanje roke (Ibid. v: Mišic, 2003, str. 33). Kazen se izreče na podlagi izjav dveh očividcev oziroma na podlagi priznanja storilca.

d) Rop

Pri izrekanju kazni za to dejanje mora sodnik upoštevati resnost kaznivega dejanja. Če storilec $v$ času ropa ubije žrtev, mu mora sodnik izreči smrtno kazen. Če storilec stvar le ukrade, se mu odrežeta roka in noga. Če storilec grozi in s tem samo prestraši žrtev, pri čemer pa nikogar ne poškoduje, bo izgnan iz države. Vendar izgon danes vse bolj zamenjuje zaporna kazen (www.infonyazee.com v: Mišic, 2003, str. 33).

e) Pitje alkohola

Pitje alkohola je bilo zlasti $\vee$ predislamski skupnosti precej razširjeno. Po verovanju naj bi Alah prepovedal pitje opojnih pijač in ukazal, da bo vsak, ki te zapovedi ne bo upošteval, kaznovan z osemdesetimi udarci z bičem. Ta prepoved danes ne velja le za pitje alkohola, ampak za zlorabo vseh opojnih substanc (tudi drog) (Ibid v: Mišic. 2003, str. 33).

f) Odpadništvo od vere (murted)

Odpadništvo od vere pomeni, da se vernik odreče islamski veri. Posledica tega kaznivega dejanja je izrek smrtne kazni. Če se pred izvršitvijo kazni obso- 
Alenka Kuhelj, Jasna Halilović

Vloga in pomen islamskega prava

jenec ne spokori, se šteje, da je odpadnik nosilec "nekakšne bolezni«, ki ne škoduje le njemu, ampak celotni družbi oziroma državi. V primeru, da se odpadnik spokori, smrtna kazen ni izvršena (www.info-nyazee.com v: Mišic, 2003, str. 34).

Kazni hudud so zelo stroge. Božji namen, ki stoji za resnostjo in strogostjo kazni, je svarilen ukaz Boga. Tako se morajo kazni izvajati pred skupino vernikov, ne le zaradi storilca kot kazen za storjeni greh, ampak tudi kot opozorilo celotni družbeni skupnosti (Mišic, 2003, str. 34). Vse opisane kazni povzročajo hude telesne bolečine obsojenim storilcem. Vedeti pa moramo tudi, da so kazni hudud izrečene zelo redko. V Savdski Arabiji so bile med letoma 1981 in 1992 štiri usmrtitve s kamenjanjem in štiriinštirideset amputacij zaradi kaznivega dejanje kraje (Motzki v: Mišic, 2003, str. 36). Le majhno število vseh kazenskih zadev se obravnava po postopku hudud, kjer se na koncu izreče kazenska sankcija hudud. Večina kazenskih zadev se obravnava po milejšem postopku tazir (Mišic, 2003, str. 36).

\subsubsection{Kisas}

Gre za kazniva dejanja, za katera je kot sankcija predvideno maščevanje (Imamović, 2005, str. 99). Pojem kisas $v$ dobesednem prevodu pomeni enak oziroma tehten. Kisas predvideva, da naj bo ravnanje $s$ storilcem enako njegovemu kaznivemu dejanju (http://www.brudirect.com/criminal/part1.htm v: Mišic, 2003, str. 41). Kazniva dejanja, za katera so določene kazni kisas, so predvsem dejanja zoper posameznikovo telesno integriteto, kot so: umor, uboj, uboj v samoobrambi, povzročitev telesne poškodbe (www.info-nyazee.com v: Mišic, 2003, str. 43). Kaznivo dejanje umora se $v$ islamskem pravu šteje za velik greh in je zlobno in prekleto dejanje (Mišic, 2003, str. 34).

V Koranu je določeno: „Predpisali smo: življenje za življenje, oko za oko, nos za nos, uho za uho, zob za zob. Rane naj se poplačajo, " (Koran v: Mišic, 2003, str. 44).

Kazni predpisuje Koran, zato sodnik pri odločanju nima diskrecijske pravice. $\vee$ samem postopku je posebej pomembna vloga, namenjena žrtvi oziroma njenim sorodnikom. Ti lahko storilcu kaznivo dejanje oprostijo in ne zahtevajo povračila, ampak krvnino (dijat), lahko pa se odrečejo tudi temu in storilcu oprostijo v celoti (Belal v: Mišic, 2003, str. 41).

Dijat oziroma krvnina je povračilo predvsem za nenaklepna kazniva dejanja, kot sta na primer nenaklepen uboj in telesna poškodba. Prvotno je bila kazen dijat oziroma krvnina nadomestilo $v$ višini stotih kamel. Nekateri šeriatski pravniki pa 
menijo, da je višina krvnine plačilo bodisi $\vee$ višini tisoč goldinarjev, dvanajst tisoč dirhem ali nadomestilo $v$ višini dva tisoč krav ali dva tisoč ovac. Večina šeriatskih pravnikov daje pri izplačilu prednost kamelam. Če teh ni dovolj, se kot alternativa dopušča plačilo $v$ višini tisoč goldinarjev. Seveda pa se vrednost kamel v zlatu in srebru spreminja (Ibid v: Mišic, 2003, str. 42).

Kazen kisas izvršijo sorodniki žrtve, če so zmožni kazen izvršiti učinkovito. $\checkmark$ nasprotnem primeru pa sorodniki žrtve določijo učinkovitega izvršitelja kazni. Tudi storilčevo družino se obvesti o kraju in času izvršitve kazni, z namenom, da se je tudi ti udeležijo. Izvršitev se opravi $v$ javnosti. Najprej se naznani storilčevo ime, nato žrtvino ime in na koncu se opiše celoten primer (El-Sa'aty v: Mišic, 2003, str. 42). Vendar se pred izvršitvijo kazni da družini žrtve še zadnjo priložnost, da si premisli in pristane na krvnino, da bi se s tem prenehalo prelivanje krvi. $\vee$ nekaterih primerih se ta trud izplača, $\vee$ drugih primerih pa družine ni moč prepričati $\vee$ to in se zato kazen izvrši (Ibid v: Mišic, 2003, str. 42).

Za izrek kazni kisas morajo biti izpolnjeni naslednji pogoji: storilec kaznivega dejanja mora biti prisebna in polnoletna oseba, ki je kaznivo dejanje storila naklepno, poleg tega pa mora biti žrtev kaznivega dejanja musliman. Kazen mora biti izvršena na najmanj boleč način za storilca, ki mu ni dopustno povzročiti večje bolečine oziroma škode, kot jo je ta povzročil žrtvi in njeni družini. Poleg tega pa mora imeti oseba, ki bo izvršila kazen (izvršitelj) primerno znanje in zmožnosti zanjo. Taka oseba je ponavadi družinski član ali pa določen profesionalni izvršitelj, ki izvrši kazen v imenu žrtvine družine (Sanad v: Mišic, 2003, str. 43).

\subsubsection{Tazir}

Med kazniva dejanja, za katera se uporabi postopek tazir ter se nato izreče kazen tazir, štejejo tista dejanja, za katera Koran in suna ne določata ničesar ali pa dejanje določata kot kaznivo, kaznovanje pa prepuščata sodnikom in vladarju (Mahmoudi v: Mišic, 2003, str. 44). Vrste kazni, ki so predvidene za ta kazniva dejanja so: bičanje, denarna kazen, globa (Imamović, 2005, str. 100). Določanje kazni $\vee$ primeru kaznivih dejanj tazir je $\vee$ diskrecijski pravici vladarja, ki pa lahko svojo pravico delegira na sodnika. Sodnik lahko izreče katerokoli kazen, za katero meni, da je primerna, vendar ne dosega stopnje in teže kazni hudud (Mejdani v: Mišic, 2003, str. 45). Pri določanju kazni mora sodnik upoštevati tri dejavnike: težo storjenega kaznivega dejanja, značilnosti storilca ter socialno potrebo po družbeni preventivi (oziroma zastraševanju) (Vogel v: Mišic, 2003, str. 45). 


\section{Alenka Kuhelj, Jasna Halilović \\ Vloga in pomen islamskega prava}

Sam postopek sodnega odločanja je $\vee$ zadevah tazir veliko enostavnejši kot $\vee$ zadevah hudud. $\vee$ postopku zadostuje pričanje dveh prič, pri čemer je dopustno tudi pričanje ženske. Eno moško pričo lahko nadomestita dve ženski priči (lbid v: Mišic, 2003, str. 46).

\section{Razmislek}

Islamskega prava, v katerem je religija $v$ tolikšni meri prevladujoča, da neposredno določa tudi vsebino prava, ni mogoče opredeliti kot sodobno pravo. Sodobna država je lahko samo tista, ki ima demokratičen politični sistem, medtem ko islamsko pravo najdemo $v$ državah z zelo različnimi političnimi sistemi, od totalitarnih do demokratičnih, kar pomeni, da islamsko pravo ni nujno vezano na določeno obliko države. Razlika med viri islamskega prava in viri sodobnega prava je precejšnja, vendar pa se je z nastankom bolj demokratičnih političnih sistemov tudi $v$ islamskem svetu pojavil sodoben način nastajanja predpisov in širše tudi nastajanje prava. Danes $\vee$ večini islamskih držav sprejemajo predpise zakonodajni organi po predpisanih postopkih, vendar pa je vsebina mnogih predpisov še vedno globoko prepletena z religijo.

Islamsko pravo ne pozna individualnosti $\vee$ obliki, kot jo pozna sodobno pravo, pozna pa predvsem dolžnosti posameznika do skupnosti in Boga. Značilnost islamskega prava je njegova vseobsežnost, saj s svojimi predpisi zaobjema tako zasebno kot tudi javno življenje, pri čemer pa je Bog izhodišče vsega.

Islamsko pravo ima svojo osnovo $v$ religiji, s katero je tako tesno povezano, da ju ni mogoče ločiti, zato se postavlja vprašanje, ali je islamski svet zmožen oziroma pripravljen sprejeti sekularizem in s tem državo ločiti od religije. To pomeni opustitev šeriata ter strogo ločitev verskega od posvetnega. Le tako lahko namreč islamski svet prevzame pravo in preizkušene pravne institute zahodnega sveta. Po drugi strani pa je islamsko pravo tako vseobsegajoče in ureja celotno življenje muslimanov, da lahko to vodi $v$ nadaljnje dosledno izvajanje šeriatskega prava in oblikovanje pravnih postopkov in pravil $\vee$ skladu $\mathrm{s}$ Koranom. Na ta način se bo islamski svet še bolj oddaljil od zahodnega sveta in razlike, ki so se $v$ preteklosti že zmanjšale, se bodo na novo poglobile.

Mogoče pa je treba na koncu izpostaviti tudi vprašanje ali islamski svet res potrebuje oziroma želi prevzeti zahodne modele sodobnega prava in sodobne države ali pa je to bolj zamisel (oziroma želja) zahodnega sveta, ki poveličuje svoje ideale demokracije in jih poskuša na neki način vsiliti tudi drugim. 
Doc.dr. Alenka Kuhelj je diplomirala na Pravni fakulteti v Ljubljani leta 1989. V letih 19901991 je bila zaposlena kot odvetniška pripravnica v odvetniški pisarni v Ljubljani. V študijskem letu 1993-1994 je na univerzi UCLA - University of California at Los Angeles v ZDA kot gostujoča raziskovalka pripravila magistrsko nalogo z naslovom: "Primerjalnopravni vidiki lokalnega samoupravljanja s poudarkom na ameriških izkušnjah", s katero je magistrirala na Pravni fakulteti v Ljubljani leta 1996. Doktorirala je leta 2003 prav tako na Pravni fakulteti v Ljubljani. Področja njenega ukvarjanja so: ustavno pravo, institucije EU, državljanstvo EU, mednarodnopravno varstvo človekovih pravic in temeljnih svoboščin, pravica do veroizpovedi in primerjalnopravni vidiki državljanstva. Od leta 2001 je aktivna članica strokovnega združenja pravnikov in družboslovcev "Law and Society Association " (LSA) s sedežem v ZDA. Leta 2005 je od ameriške vlade prejela prestižno Fulbrightovo postdoktorsko štipendijo in bila kot štipendistka sprejeta na Harvard University (Law School), Massachusetts, ZDA. Po vrnitvi v domovino je na Fakulteti za upravo predstojnica za mednarodne izmenjave.

Jasna Halilović je diplomantka Fakultete za upravo.

\section{Literatura in viri}

- Afshar, H.(1999): Islam and Feminisms. An Iran Case-Study. University of York.

- Bošnjaković, D. (2007): Položaj muslimanov v Sloveniji - (ne)gradnja islamskega kulturnega centra $\vee$ Sloveniji. Diplomska naloga, Fakulteta za Socialno delo, Ljubljana.

- Čerimović, M.A.(1936): Šeriatsko nasljedno pravo. Mešihat Islamske zajednice u Republici Hrvatskoj i Sloveniji, Sarajevo.

- Česnik, M.(2001): (Ne)enakost spolov v islamskem pravu. Diplomska naloga, Pravna fakulteta, Ljubljana.

- $\quad$ Fyzee, A.(1974): Outlines of Muhammadan Law. Oxford University Press.

- Grasmann, G. David, R.(1998): Uvod v velike sodobne pravne sisteme. Cankarjeva založba, Ljubljana.

- Imamović, M.(2005): Predavanja iz opće povjesti prava i političkih institucija. Sarajevo.

- Janežič, D.(2006):Vpliv islamskega prava na državno pravo Egipta. Diplomska naloga, Pravna fakulteta, Ljubljana.

- Karanović, T.(1998): Zakonska zveza v šeriatskem pravu. Diplomska naloga, Pravna fakulteta, Ljubljana.

- Karčić, F.(1997): Študije o šeriatskom pravu. Bemust, Zenica.

- Kuhar, A.(2007): Položaj žensk(e) islamskem pravu. Diplomska naloga, Pravna fakulteta, Ljubljana. 
Alenka Kuhelj, Jasna Halilović

\section{Vloga in pomen islamskega prava}

- Kuhelj, A.(2004): Križi in rute. Mladina, 2004, št. 51, str. 40 - 42.

- Mišic, D.(2003): Kaznovanje v islamskem pravu. Diplomska naloga, Pravna fakulteta, Ljubljana.

- Munh, L. (1998): Temeljne značilnosti islamskega prava. Diplomska naloga, Pravna fakulteta, Ljubljana.

- Pašić,A.(2006): Islam in moderni zahod. Gorenjski glas, Kranj.

- Pavlica,V.(2004): Pravni vidiki Korana. Diplomsko delo, Pravna fakulteta, Ljubljana.

- Prevolšek, M.(1989): Kazensko pravo v Koranu. Diplomsko delo, Pravna fakulteta, Maribor.

- Smailagić, N.(1976): Klasična kultura islama. Zagreb.

- $\quad$ Smrke, M.(2000): Svetovne religije. Fakulteta za družbene vede, Ljubljana.

- Trtnik, T.(2006): Pomen idžme za islamsko pravo. Diplomska naloga, Pravna fakulteta, Ljubljana.

- $\quad$ Cerkvena poroka - islamska skupnost - zajednica, http://www.eporoka.com/sl/cerkvena-poroka/ISLAMSKA_SKUPNOST-ZAJEDNICA_/)

- $\quad$ Mag - Drama na Bosporju; http://www.mag.si/index.php?option=com_content\&task=view\&id=1056\&ltemid=55

- $\quad$ Religije.com/islam, http://www.religije.com/islam.htm

- Wikipedija, prosta enciklopedija, http://sl.wikipedia.org/wiki/Ramadan

- Wikipedija, prosta enciklopedija, http://sl.wikipedia.org/wiki/Had\%C5\%BE 


\section{SUMMARY}

\section{THE ROLE AND IMPORTANCE OF ISLAMIC LAW}

The question of Islam in Europe raises a set of domestic policy issues about the relationship between church and state. There is a clash of values, but perhaps the most important is that between two old European parties, secularists and conservatives, as each struggles to come to terms with religious pluralism. Samuel P. Huntington says the world today is facing "a clash of civilizations" and "cultural war". These apocalyptic pronouncements are not only counterproductive. They are dangerously misleading.

At the heart of Islamic law lie the teachings of God and the acts and sayings of his prophet, Muhammad. Islamic law or Sharia, is founded on the Qur'an and the Sunnah. However, sharia was not fully developed at the time of Muhammad's death, but rather it evolved around the Muslim community through which it would serve. After the death of Muhammad Sharia continued to undergo fundamental changes. When Sharia began its formation in the deserts of Arabia, a sense of community did not exist. Life in the desert was nomadic and tribal, thus the only factor that tied people together into various tribes was through common ancestry. However, the nature of Islam challenged that ideology and brought all those who professed their submission to Islam into the Ummah. Additionally, Islam was not just a religion but a way of life that transformed those who were once enemies into neighbors. Laws had to be instilled so the doctrines of Sharia took root. All who are Muslim are judged by Sharia - regardless of the location or the culture.

Sharia is Islamic religious law. The term means "way" or "path to the water source" and is the legal framework within which the public and private aspects of life are regulated for those living in a legal system based on Islamic principles. Sharia deals with many aspects of day-to-day life, including politics, economics, contracts, family and social issues. It is more of a system of law, because it is a consensus of the "spirit", based on the Qur'an (which is the religious text of Islam).

Before the 19th century, legal theory was considered the domain of the traditional legal schools of thought. Islamic law is now the most widely used religious law, and one of the three most common legal systems of the world alongside common law and civil law. During the so called Islamic Golden Age, classical Islamic law may have influenced the 
Alenka Kuhelj, Jasna Halilović

Vloga in pomen islamskega prava

development of common law, and also influenced the development of several civil law institutions.

The primary sources of Islamic law are the Qur'an and Sunnah.

To this, traditional Sunni Muslims add the consensus of Muhammad's companions and Islamic jurists on certain issues, and drawing analogy from the essence of divine principles and preceding rulings. The consensus of the community or people, public interest, and others are also accepted as secondary sources where the first four primary sources allow.

Shi'a Muslims reject this approach. They strongly reject analogy as an easy way to innovations, and also reject consensus as having any particular value in its own. During the period that the Sunni scholars developed those two tools, the Shi'a Imams were alive, and Shi'a view them as an extension of the Sunnah, so they view themselves as the only deriving their laws from the Qur'an and Sunnah. A recurring theme in Shi'a jurisprudence is logic, something Shi'a believe they mention, and value to a higher degree than Sunnis do. They do not view logic as a third source for laws, rather a way to see if the derived work is compatible with the Qur'an and Sunnah.

In Imami-Shi'i law, the sources of law are the Qur'an, anecdotes of Muhammad's practices and those of the Imams, and the intellect. The practices called Sharia today, however, also have roots in local customs.

The Five Pillars of Islam is the term given to the five duties incumbent on every Muslim. These duties are Shahadah (profession of faith), Salat (ritual prayer), Zakat (almsgiving), Sawm (fasting during Ramadan) and Hajj (pilgrimage to Mecca). These five practices are essential to Sunni Islam. The Quran reveals the "five pillars" of Islam, the five ritual expressions that define orthodox Muslim religious belief and practice. Shahadah is professing oneness of Allah and accepting Prophet Muhammad as his messenger to humanity. The second pillar of Islam is Salat, the requirement to pray 5 times a day at fixed times during the day. The time of day to pray are at dawn, noon, mid-afternoon, sunset, at night. Each salat is performed facing towards the Kaaba in Mecca. Zakaat or alms-giving, is the practice of charitable giving by Muslims based on accumulated wealth, and is obligatory for all who are able to do so. It is considered to be a personal responsibility for Muslims to ease economic hardship for others and eliminate inequality. Ritual fasting (Sawm) is an obligatory act during the month of Ramadan. Muslims must abstain from food, drink, and sexual intercourse from dawn to dusk during this month, and are to 
be especially mindful of other sins. The fast is meant to allow Muslims to seek nearness to Allah, to express their gratitude to and dependence on him, to atone for their past sins, and to remind them of the needy. The Hajj is a pilgrimage to the holy city of Mecca, and derives from an ancient Arab practice. Every able-bodied Muslim is obliged to make the pilgrimage to Mecca at least once in their lifetime if they can afford it.

For Islam, God is the ultimate lawgiver. The Sharia is sacred law, or "the law of God". It consists of the maxims, admonitions, and legal sanctions and prohibitions enshrined in the Qur'an and explained, elaborated, and realized in the prophetic tradition.

In theory, Islam is a "nomocracy"- a government of laws, not of people. Ideally, the purpose of an Islamic government is to ensure that God's law is followed in human society.

The status of the Muslim headscarf- the hijab- has provoked more debate about Islam in Europe than any other issue. This is because it seems to sum up so many of the concerns that trouble Europeans when they consider the Islamic minority in the midst. In 2004 the French government and five German state governments passed legislation to prohibit the wearing of the Muslim headscarf. Berlin passed a ban in February 2005. In Germany, the law affects teachers in public schools, and sometimes public employees generally, but not students. In France, only the students are affected. The ostensible reason for banning the scarf in both countries was the need to protect fundamental public values, but the endangered values apparently at stake were different, and the prohibitions were differently tailored. France and Germany are the only countries to have taken legislative action to date, but headscarf controversies are everywhere. 